\title{
College Music Innovation Teaching under the Background of Quality Education
}

\author{
Xiuli Wang \\ (Moscow School of Arts, Weinan Normal University, Weinan 714099, PR China)
}

Keywords: Quality education; College music; Innovative teaching

\begin{abstract}
Quality education refers to a form of education aimed at improving the quality of all aspects of educated people. Under the background of quality education, innovative music education for college is a comprehensive expression that we hope to attach great importance to college students' ideological and moral qualities and abilities. University music education needs to be based on individual development, and to carry out a systematic education on college students' physical health and music promotion. Quality education is a puzzle-based approach to education, which is an important tenet of our higher education program. Music education is an important component of higher education programs in our country. Different from other teaching contents, music teaching is an aesthetic education content with artistic appeal, which can greatly improve students' English accomplishment and ability to perceive music and the outside world. Therefore, music teaching can cultivate students' unique charm and creation.
\end{abstract}

\section{Introduction}

Under the background of quality education, there are a series of problems in the innovative method and innovative mode of university music teaching. University music teachers may not be good at using other learning method and teaching mode except sight-singing in the actual teaching process. Therefore, in view of the current situation of college students' music learning and the situation of college music education, it is hoped that we can effectively innovate music teaching mode and improve music teaching methods, and also help the music teaching and lecture mode of colleges and universities to be enhanced with richer wisdom and knowledge. At the same time, enhance college music teaching and lecture mode with a wealth of wisdom and knowledge, so that the hearts of students and teachers are better enlightenment and baptism, which will help students and teachers to interact in the process of music learning.

\section{The Importance of Quality Education in College Music Innovation}

The background of quality education undoubtedly plays a very important role in university music learning and music innovation. Music teaching is a contagious teaching model. Educational research suggests that students' interest in music and the outside world helps to develop students' comprehensive personality and creativity. Therefore, under the background of quality education, strengthening the teaching and learning mode of university music innovation can change the traditional teaching mode. In the actual process of college English teaching, classroom teaching method is adopted to show the dominant position of students according to the needs of the outline of music teaching.

Broaden the Horizons of Music Majors. Broaden the horizons of music is the important innovation for college music teaching under the quality education. This is because the previous teaching mode only allows students to learn the theory of musical theory, but the teaching content adopts the same rigid teaching material, which denies students' interest in learning and can not effectively open up students' horizons. Therefore, in the context of quality education, university teachers can be required to be fun with students. In the process of teaching, paying attention to students, speeding up student learning and enhancing their confidence and creativity of learning is the key and core of music education. Teachers should try their best to enhance students' aesthetic conception with a variety of musical themes, broaden students' horizons with the selected song 
content, cultivate their interest in music learning and skills and understand the latest popular music forms in the international music world. Learning many elegant musics can make the whole music teaching process more interesting and using multimedia can mobilize learning atmosphere in classroom.

Promote the Cultural Accomplishment of Music Majors. The cultural accomplishment of music majors is one of the basic contents of music learning. This is because the cultural literacy will affect the perception of music learning and aesthetic concepts. Clear the goal of quality education and re-position music education resources. Enhance the cultural quality of college students in music issues through effective teaching resources and combined with the customs of our country custom and ethnic music. It can provide more rich and colorful teaching aids to education and learners by effectively broadening educational resources, especially for the professions that are connected with the arts. For example, the study of Chinese language enables students to quickly understand and remember when they are taught music learning knowledge and basic music theory knowledge. Educators and front-line teachers should screen out the most effective educational resources and modes within a short period of time so as to enhance students' learning pleasure and guide students to construct a positive musical support and rich musical education comprehension.

Use Music to Relieve the Stress of Life. Many college students may face some competitive pressures in the intense learning process due to the combined effect of cultural accomplishment and academic performance. Besides, college students will continue to put pressure on themselves taking into account future employment prospects. However, these pressures of life can be completely relieved by music as music is the best solution to the pressure of life. After a long period of education reform, music enters people's life. Music is just as good as the food and the unique charm and emotion of the music that can be understood by college students. There is a rich emotional experience behind each piece of music composition. These emotional experiences and stories are the ultimate goal and starting point for students to learn music. They are also the lasting power source for students to learn music.

\section{Problems in College Innovative Music Teaching}

Even in the continuous process of innovation, we still face many problems. This is because the teaching and learning of music is compatible with each other. There may be a series of problems in the process of learning., so there are also various solutions to the problems in the process of teaching.

Teaching Mode Can Not Be Combined with Rigid Teaching Methods. It is the primary problem in the process of music teaching in colleges and universities. This is because many schools still use traditional methods of singing and hearing to teach music. Multimedia teaching can help teachers and students to feel and listen the music, but it did not really play its role. If the rigid teaching mode can not improve, students have no enthusiasm for music learning, which is not helpful for students to learn music.

Outdated Teaching Methods Make Teaching Emotional Exhausted. Education is a job that needs constant innovation. In the past few thousand years, many changes have taken place in the educational forms in China. At present, music teaching in university restricts the content and method of students' learning in teaching behaviors and teaching achievements. In order to be able to effectively mobilize the teaching emotions, people have made a lot of positive efforts. However, due to the tight schedule and heavy tasks of music teaching, many college music teachers have already lost their interest in music. Instead, they tend to be more rigid in their teaching mode and ignore quality education. For music, which develop based on emotion and aesthetic, the depletion of teaching emotion is very terrible.

Single Teaching Content and Fixed Teaching Scene. There is a problem of university music teaching that teaching content is very monotonous. In the teaching scene is relatively fixed circumstances, rich teaching resources failed to bring rich teaching content. Therefore, single teaching mode and fixed teaching scene can not really affect student's thinking. Many college students regard music lessons as an elective course and they just listen to music in music lessons. 


\section{The Quality Education Measures of University Innovative Music Teaching}

To reasonably adjust the teachers' ranks and strictly observe the teacher's resources will be the key to improve the quality of music teachers. As college students' outlook on life and values are basically stereotyped, teachers only need to enhance their interest in music learning when teaching basic music knowledge. Besides, teachers should provide students with colorful learning skills and learning resources so that they can learn independently.

Clarify Teaching Objectives and Positioning. In the teaching process, we must grasp the clear goal of music teaching and positioning. This is because quality education is an education method aimed at improving people's basic qualities in an all-round way. Music can make the best use of the situation, grasp the aesthetic concept and enhance the ability of perception of art. Besides, quality education can help students enhance their competitiveness in all aspects. Therefore, strengthening the formulation of the goal of university music learning and helping undergraduates understand each level and height that they should raise musical literacy and perception at every stage will be an important task for university teachers in the future to teach in the music class.

Pay Attention to the Quality of Basic Students. The quality of the basic students is an important area for college students to enter the university. However, cultural class scores is the only quality standards. At the same time, teachers should help students learn the art-related cognitive abilities in the process of university music and quality learning. How to improve the acute aesthetic conception should be the prerequisite for universities and colleges to screen talents and prepare for basic study in the future. Only college students keenly grasp the basic learning content, they can make thinking more spiritual. In music teaching process, the quality of music will affect the actual effect of music teaching. Therefore, colleges should examine the students' basic music knowledge, music theory, interest and enthusiasm for music learning in the entrance examination process.

Pay Attention to Music Aesthetic and Music Teaching Practice. The music aesthetic and music teaching practice will be the important teaching content of future university music innovation teaching. It should be improved that music teaching can not meet the need of improving students' comprehensive monthly value. If the teaching methods can infiltrate the content of music aesthetic and music appreciation, then teachers can use music videos or music animation in the future practice of music teaching and enhance the interesting for college music classes combined with the teaching of computer multimedia. The basic quality of college students should include musical aesthetic and music teaching. Besides, when students imitate the teacher and listen to the teachings of teachers, they can also listen to the intersection of music. Music is a special language, a description of the beauty of human emotions and human rules. Therefore, strengthening the comprehension of this emotion requires teachers to grasp the comprehensive influence of music auditorium on college students from different aspects.

Combine Music and Dance to Enhance Expressiveness. Traditional college music teaching is often used as an elective. However, in the new university lecture hall, college students should be encouraged to get out of the classroom and work with teachers in the rehearsal room to combine music with dance and conduct regular dance classes and physical training. Although many undergraduates have a weak foundation, teachers can create interesting courseware based on the students' interests and teach them step by step. At the same time, teachers should provide more colorful classroom content for college students. Music lessons as an important elective course, college students can learn music according to their own interests and choose what they like. Meanwhile, the assessment content of teachers should be based on the actual choice of students, which can broaden the knowledge of music learning for students and give them to make more choices.

\section{Conclusion}

The continuous development of music teaching and classroom reform mode makes music education occupy more and more important position in quality education. To enhance students' overall literacy and spirituality will start with the enhancement of musical education. To improve the current 
situation of music teaching in colleges and universities in our country is not ideal. Improving unideal effect of music teaching and exploring method of music education in colleges and universities will be an important starting point for reversing the educational thinking and changing the effectiveness of music teaching in the future.

\section{Acknowledgements}

Fund Project: This work was financially supported by Scientific Research Program of Weinan Normal University(No.2015JYKX011)

\section{References}

[1] B. Li and Y. D. Zhang. The Cultivation Strategy of Humane Quality in College Music Education [J / OL]. Voice of the Yellow River, 2017, (19): 49 (2017-12-04).

[2] Y. J. Xie. The Function Analysis of University Music Appreciation and Quality Education [J / OL]. China Training, 1 (2017-06-15).

[3] S. D. Li. Vocal Music Teaching Method in Quality Education [J]. Art Research, 2016, (02): 218-220.

[4] L. Tian. Teaching Innovation under the Quality Education of Music Major Students in Colleges and Universities [J]. Journal of Hubei Correspondence University, 2015,28 (17): 115-116.

[5] Y. Qing. Innovative Curriculum Reform of Music Quality Education in Comprehensive Universities - A Case Study of Shanghai Conservatory of Music [J]. Voice of the Yellow River, 2015, (09): 36-38.

[6] Y. Chen. Music Teaching and Practice in Colleges and Universities from the Perspective of Cognitive Learning Theory [D]. Shanghai Conservatory of Music, 2012.

[7] X. L. Zhang. Research on College Students' Music Quality Education Based on Innovative Thinking [D]. Dalian University of Technology, 2011.

[8] J. Q. Liao. Innovation and Exploration of Quality-oriented Education and Teaching for Music Majors in Universities [J]. Science \& Technology Information, 2007, (05): 142.

[9] L. P. Chang. A Tentative Idea on Curriculum Construction of Music Quality Education in Colleges and Universities [D]. Central China Normal University, 2006.

[10]N. Xue. On the Combination of Classics and Popularity in College Music Quality Education [J]. Journal of Ningbo University (Educational Science Edition), 2006, (01): 119-121.

[11]J. Zhang. Teaching Research on Common Music Courses in Universities of Science and Engineering [D]. Nanjing Normal University, 2005.

[12]L. H. Nan. Music Education in University Quality Education [J]. Higher Education Research, 2000, (06): 60-63. 